\title{
Effect of Adjuvant Vitamin C on Brain-Derived Neurotrophic Factor Levels and Improvement of Negative Symptoms in Schizophrenic Patients
}

Andi Jayalangkara Tanra ${ }^{\mathbb{D}}$, Herwina Sabaruddin*, Kristian Liaury, Andi Alfian Zainuddin, Hawaidah Hawaidah, Bukhari Agussalim, Syamsuddin Saidah, Lisal T. Sonny

Department of Psychiatry, Medical Faculty, Hasanuddin University, South Sulawesi 90245, Indonesia

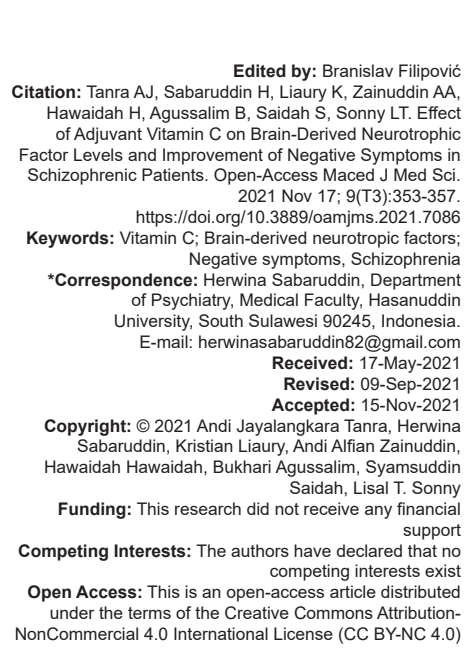

Abstract

AIM: This study aims to determine the effect of adjuvant Vitamin C on brain-derived neurotropic factors (BDNF) levels and improvement of negative symptoms in schizophrenic patients.

METHODS: This study was conducted at Hasanuddin University Hospital and its affiliate with 60 schizophrenic patients ( 30 controls, 27 treatments, and three dropout patients). The ELISA sample examination method was used to examine blood levels of BDNF, and Vitamin C levels before and after administration of Vitamin C. In addition, the negative symptoms were measured using the PANSS score.

RESULTS: There was a significant increase in BDNF levels in treatments group compared the control at 4th-8th weeks with $p=0.005$ (4th week) and $\leq 0.0001$ (<0.05) (8th week). The improvement in PANSS scores for negative symptoms in the treatment groups compared to the controls at the 2 nd, 4th, and 8th weeks resulted in $p=0.042$ (2nd week) and $<0.0001$ (4th-8th weeks). Furthermore, there was an increase in serum Vitamin C levels in the treatment groups with an initial average value $=4.762$ and after 8 weeks $=148.155$. Strong correlation between increased BDNF levels and improvement in negative symptoms on the PANSS score was found with $p=0.001$ (4th week) and $\leq 0.0001$ (8th week).

CONCLUSION: The administration of Vitamin C significantly increases BDNF levels and improves the PANSS score for negative symptoms in the treatments compared to the control groups.

\section{Introduction}

Schizophrenia is a complex, multifactorial, and chronic psychiatric disorder with numerous negative symptoms and impacts on sufferers and the environment [1], [2]. Meanwhile, negative symptoms are a major component of schizophrenia and cause most of the longterm disability and poor prognosis in patients with this disorder. The term negative symptom describes a reduction or loss of normal behavior and function related to motivation and interest, as well as verbal/emotional expression. The negative symptom domain of schizophrenia usually consists of these five signs, namely, lack of emotional expression, alogia (reduction in the number of words spoken), avolition (reduction in goal-directed activities due to decreased motivation), antisociality, and anhedonia (reduced pleasurable activities) [3], [4].

Aside from the negative symptoms, one of the neurotrophins predicted to play a role in the disruption of dopamine activity is BDNFs. Furthermore, BDNF plays a role in neuronal development and plasticity [5], [6]. It regulates aspects of developmental plasticity in the brain and is involved in cognitive function as well as its related negative symptoms [7]. Similar to other neurotrophins, the role of brain-derived neurotrophic factor (BDNF) was initially identified in neuronal proliferation, neurogenesis, differentiation, and degeneration. Furthermore, BDNF function in regulating activity-dependent neuron modification has been described. For example, it regulates both memory formation and long-term potentiation, as an activity-dependent reinforcement of synaptic efficacy [8].

Ascorbic acid (Vitamin C) is an antioxidant vitamin and plays an important role in protecting against free radical damage in the body. It is found in brain tissue and dopamine dominant areas with higher concentrations compared to other organs [9]. A prospective double-blind placebo-controlled study of 40 outpatients in India examined Vitamin C supplementation (500 mg/day) for 8 weeks in patients with schizophrenia taking second-generation antipsychotics [10]. The previous studies also showed that Vitamin C supplementation improves negative symptoms in schizophrenic patients and reduces free radical-induced brain damage [11], [12]. 
An observation on the effect of Vitamin $C$ at a dose of $1000 \mathrm{mg} /$ day on schizophrenic patients by assessing the PANSS score observed during weeks 8-16 which showed improvement in negative symptoms and elevated levels of dehydroascorbic acid [11], [12], [13], [14]. Although some studies are controversial, most of the data show an association between ascorbic acid levels and schizophrenia symptoms [10]. Furthermore, the potential use of Vitamin $\mathrm{C}$ as a therapeutic adjuvant in the treatment of schizophrenia needs to be exploited.

Therefore, due to the lack of studies on the effect of Vitamin $C$ in improving clinical negative symptoms and changes in BDNF levels in schizophrenia patients, as well as the controversy on the patients' blood before and after Vitamin $\mathrm{C}$ administration, this study aims to examine the effect of Vitamin $\mathrm{C}$ on the improvement of negative symptoms in schizophrenia patients and BDNF levels.

\section{Subjects and Methods}

A total of 60 samples divided into two groups were used in this experimental study with a pre- and post-test control group design, where Group I consisted of 30 respondents given a placebo as a control, and Group II consisted of 30 respondents given Vitamin C at a dose of $1000 \mathrm{mg} /$ day. The inclusion criteria for each group were schizophrenia patients diagnosed based on DSM V aged 18-50 years, using atypical antipsychotic therapy doses (risperidone and clozapine), and initial serum Vitamin C levels of $1-300 \mathrm{ng} / \mathrm{ml}$. Meanwhile, the exclusion criteria include patients with comorbid physical disease disorders, such as impaired liver and kidney function, diabetes, neurological and cardiovascular disease, history of substance, and antioxidant use during the previous 1 week. The respondents were recruited from the Special Regional Hospital of Dadi South Sulawesi Province.

The BDNF and Vitamin C levels were assessed using ELISA through the patient's blood of 3cc obtained from the median cubital vein. Furthermore, the sample was centrifuged and serum was inserted into blank, standard, and sample wells. In the blank wells, blood samples and horseradish peroxidase (HRP) were not added, meanwhile, $50 \mu$ of standard solution was added to the standard well, while $40 \mu$ of special solution and $10 \mu \mathrm{l}$ of serum were added to the sample well. Furthermore, $50 \mu$ l of HRP was added to each except the blank wells and the plate was then covered, lightly shake and incubated for $60 \mathrm{~min}$ at $37^{\circ} \mathrm{C}$. The BDNF levels and improvement of negative symptoms were measured at the $2^{\text {nd }}, 4^{\text {th }}$, and $8^{\text {th }}$ weeks. Moreover, the measurement of negative symptoms was based on the PANSS score, while Vitamin $\mathrm{C}$ levels were measured at the beginning and end of the study. Statistical analysis was performed using the SPSS version 22.0 for Windows.

\section{Results}

Based on the statistical tests, the data obtained include the characteristics and distribution of the subject, as well as the relationship of various variables with the PANSS value of negative symptoms and the samples' BDNF. The samples were between 20 and 50 years old. Table 1 shows the demographic characteristics of subjects.

Table 1: Demographic characteristics of subjects

\begin{tabular}{llll}
\hline Characteristics & Control $(\mathrm{n}=30)$ & Treatment $(\mathrm{n}=27)$ & $\mathrm{p}$-value \\
\hline Age (Mean \pm SD) & $35.81 \pm 7.00$ & $35.68 \pm 7.644$ & 0.904 \\
Gender & & & \\
$\quad$ Male & $25(83.3 \%)$ & $23(85.2 \%)$ & 0.849 \\
$\quad$ Female & $5(16.7 \%)$ & $4(14.8 \%)$ & \\
Education & $18(60 \%)$ & $9(33.3 \%)$ & $0.015^{*}$ \\
$\quad$ Elementary school & $8(26.7 \%)$ & $7(25.9 \%)$ & \\
$\quad$ Junior high school & $4(13.3 \%)$ & $9(33.3 \%)$ & \\
$\quad$ Senior high school & $0(0 \%)$ & $2(7.4 \%)$ & \\
$\quad$ Bachelor & & & \\
$\quad$ Types of schizophrenia & $5(16.7 \%)$ & $13(48.1 \%)$ & 0.358 \\
$\quad$ Paranoid & $25(83.3 \%)$ & $14(51.9 \%)$ & \\
$\quad$ Non-paranoid & $2.37 \pm 1.145$ & $2.70 \pm 1.263$ & 0.298 \\
Length of treatment (Mean \pm SD) & $19.50 \pm 3.693$ & $20.74 \pm 2.569$ & 0.263 \\
IMT (Mean \pm SD) & $39.07 \pm 5.199$ & $38.74 \pm 5.281$ & 0.773 \\
Initial PANSS ((Mean \pm SD) & $0.795 \pm 0.341$ & $1.0595 \pm 0.417$ & $0.014^{* *}$ \\
Initial BDNF (Mean \pm SD) & B. & & 0.749 \\
Initial Vitamin C (Mean \pm SD) & $5.501 \pm 6.499$ & $4.761 \pm 5.635$ & \\
\hline Significance test: ${ }^{*}$ Chi-square, ${ }^{*}$ Mann-Whitney U-test. & &
\end{tabular}

Based on the Mann-Whitney U-test as shown in Table 2, there were no significant differences in age, gender, occupation, marital status, body mass index, and type of schizophrenia in the treatment and control groups ( $p>0.05$ ). Therefore, it was concluded that the data above are homogeneous. Moreover, to examine the comparison of PANSS values for negative symptoms was conducted in the control and the treatment groups. The demographic characteristics are in line with a previous study which stated that the most common age for schizophrenia is in the productive range or young adults [1]. The schizophrenia diagnosis generally occurs in young adults (or in late adolescence) with onset ranging from 18 to 25 and 25 to 35 years in males and females, respectively [13]. However, rare onset occurs at an early age below 10 years (early-onset schizophrenia) and an advanced age over 50 years (late-onset schizophrenia) [14].

Table 2: Comparison of PANSS values for negative symptoms in the control and treatment groups

\begin{tabular}{|c|c|c|c|}
\hline \multirow[t]{2}{*}{ Comparison } & \multicolumn{2}{|l|}{ Mean \pm SD } & \multirow[t]{2}{*}{$\mathrm{p}$-value } \\
\hline & Control $(n=30)$ & Treatment $(n=27)$ & \\
\hline Initial PANSS & $39.07 \pm 5.199$ & $38.74 \pm 5.281$ & 0.773 \\
\hline PANSS $2^{\text {nd }}$ week & $32.67 \pm 4.950$ & $35.67 \pm 6.239$ & 0.042 \\
\hline PANSS $4^{\text {th }}$ week & $29.23 \pm 4.569$ & $23.07 \pm 5.690$ & 0.0001 \\
\hline PANSS $8^{\text {th }}$ week & $27.20 \pm 4.773$ & $13.19 \pm 4.860$ & 0.0001 \\
\hline
\end{tabular}

The comparison of PANSS values for negative symptoms in the control and treatment groups measured at $0,2^{\text {nd }}, 4^{\text {th }}$, and $8^{\text {th }}$ weeks is presented in Table 2 . 
The statistical results of the Mann-Whitney U-test in Table 2 showed a significant difference $(p<0.05)$ after the $8^{\text {th }}$ week in PANSS values of the control and treatment groups. In addition, the mean PANSS value in the initial week was greater than the $2^{\text {nd }}$ week in the two groups, and there was a significant decrease in the PANSS value. The PANSS scores of the $8^{\text {th }}$ week showed a significant decrease in the atypical antipsychotic and Vitamin $\mathrm{C}$ adjuvant group (median rank 13.19) compared to the atypical antipsychotic group (median rank 27.20), therefore, there was a larger significant difference $(p<0.0001)$. This proves that Vitamin $C$ provides improvements to the negative symptoms of schizophrenic patients. A study [10] showed that in an 8-week double-blind study on 40 controlled schizophrenia patients in India showed that the administration of atypical antipsychotics and Vitamin C at a dose of $500 \mathrm{mg} /$ day significantly decreased serum malondialdehyde indicative of oxidative stress and increased plasma ascorbate levels $(20.41 \pm 2.84$ at baseline vs. $22.79 \pm 2.27$ after 8 weeks of treatment) [5]. In the same study, concomitant administration of ascorbic acid (500 mg/day) and atypical antipsychotics had similar results, but plasma ascorbate levels were higher $(21.51 \pm 2.84 \mathrm{M} / \mathrm{L}$ at baseline and $33.54 \pm 2.84 \mathrm{M} / \mathrm{L}$ after 8 weeks of treatment). Ascorbic acid inhibits binding at the site of dopamine receptor agonists. In this study, the high concentration of ascorbic acid reduced the action of dopamine and simultaneously potentiated the effect of drugs acting on the antagonist pathway. Furthermore, it plays an important role in anti-superoxide radicals by blocking the Colamin autoxidation, thereby inhibiting the formation of potentially toxic by-products such as 6-hydroxy dopamine (6-OHDA), semi-quinone, hydrogen peroxide, and hydroxyl radicals. This resultantly inhibits nerve damage in the brain and symptoms of developmental disability [15].

In addition, the test showed the changes in serum Vitamin $\mathrm{C}$ levels in the treatment group. The results showed the changes in serum vitamin $\mathrm{C}$ level in the initial week and week 8 on the treatment group (Table 3 ).

Table 3: Changes in serum Vitamin $\mathrm{C}$ levels in the treatment group

\begin{tabular}{llll}
\hline Comparison & Median (Min-Max) & Mean & -value \\
\hline Vitamin C in 0 week & $0.842(0.05-18.96)$ & 4.762 & 0.0001 \\
Vitamin C at $8^{\text {th }}$ week & $153.459(93.8-225.17)$ & 148.155 & \\
\hline${ }^{*}$ Significant at 0.05 (Wilcoxon test); $(n=27)$. & &
\end{tabular}

Table 3 demonstrates that there were changes in Vitamin C blood levels in the treatment group from the initial to week 8 which indicated that there was an increase in ascorbic acid levels in the treatment group. This is in line with the previous studies which reported that schizophrenic patients experience a deficiency of ascorbic acid levels in the blood [16], [17]. Meanwhile, increased levels of Vitamin $C$ in the blood inhibit brain damage due to oxidative stress and increase NMDA levels, which resultantly elevate serum BDNF levels in the brain, especially the prefrontal cortex [18].
The findings also showed that there was a significant difference in Vitamin $C$ levels in the initial and $8^{\text {th }}$ week in the treatment groups $(p<0.05)$. To compare serum BDNF levels in the treatment and control groups, a total of 57 schizophrenic patients that received atypical antipsychotic therapy at therapeutic doses were measured for serum BDNF levels at the 0 and $8^{\text {th }}$ weeks. The results are shown in Table 4.

Table 4: Comparison and changes of serum BDNF levels in the treatment and the control groups

\begin{tabular}{|c|c|c|c|}
\hline \multirow[t]{2}{*}{ Item } & \multicolumn{2}{|l|}{ Mean \pm SD } & \multirow[t]{2}{*}{$\mathrm{p}$-value } \\
\hline & Control $(n=30)$ & Treatment $(n=27)$ & \\
\hline BDNF in 0 week & $0.795 \pm 0.341$ & $1.0595 \pm 0.417$ & 0.014 \\
\hline BDNF in $4^{\text {th }}$ week & $1.152 \pm 0.366$ & $1.514 \pm 0.452$ & 0.005 \\
\hline BDNF in $8^{\text {th }}$ week & $1.519 \pm 0.400$ & $2.553 \pm 0.649$ & 0.0001 \\
\hline BDNF difference between 0 and $4^{\text {th }}$ week & $1.951 \pm 0.6483$ & $2.574 \pm 0.755$ & 0.003 \\
\hline BDNF difference between 0 and $8^{\text {th }}$ week & $2.313 \pm 0.635$ & $3.613 \pm 0.920$ & 0.0001 \\
\hline BDNF difference between $4^{\text {th }}$ and $8^{\text {th }}$ week & $2.664 \pm 0.701$ & $4.067 \pm 1.043$ & 0.0001 \\
\hline
\end{tabular}

The findings showed that there was a significant difference in serum BDNF levels from the initial to $8^{\text {th }}$ week between the treatment and control groups $(p<0.05)$. Moreover, Table 4 shows that there was a significant difference in the BDNF levels for the $8^{\text {th }}$ week between the treatment and the control groups $(p<0.05)$. Tables 4 shows the changes in BDNF levels from the initial week before Vitamin $C$ administration, where the $4^{\text {th }}$ week has a $p<0.005$ and $8^{\text {th }}$ week has $p<0.0001$. This indicates that Vitamin $C$ affects changes in BDNF levels compared to the control group due to its characteristic as an antioxidant in increasing BDNF levels, while BDNF functions in neuroplasticity and other neurotransmitter regulators [19], [21]. Finally, the test was conducted to test the relationship between PANSS values and initial week serum BDNF levels and the relationship between PANSS values and serum BDNF levels at the $8^{\text {th }}$ week in the treatment and the control groups. Furthermore, BDNF is strongly associated with negative symptoms as empirically evidenced in Table 5.

Table 5: The relationship between PANSS values and serum BDNF levels in the initial week on the treatment and control groups

\begin{tabular}{ll}
\hline PANSS & $\operatorname{BDNF}(\mathrm{n}=57)$ \\
\hline 0 week & $\mathrm{r}=-0.722 ; \mathrm{P}<0.0001$ \\
$8^{\text {th }}$ week & $\mathrm{r}=-0,722 ; \mathrm{P}<0.0001$ \\
\hline
\end{tabular}

The results as presented in Table 5 showed that the correlation between PANSS values for negative symptoms and serum BDNF levels in the initial week was insignificant $(p>0.05)$ and has weak correlation strength with negative direction. In examining the relationship between PANSS values and serum BDNF levels at the $8^{\text {th }}$ week in the treatment and the control groups, the results showed that the correlation between PANSS values for negative symptoms and serum BDNF levels at the $8^{\text {th }}$ week was significant $(p<0.05)$, and shows a strong correlation with negative direction.

The close relationship between BDNF levels and improvement in negative symptoms is closely 
related to decrease BDNF levels compared to patients with positive symptoms through a glutamatergic mechanism [20], [21], [22], [23], [24]. Moreover, an increase in BDNF levels through Vitamin Cadministration to active people [25] is expected to improve the negative symptoms of schizophrenic patients. The previous studies implicate brain glutamatergic abnormalities in the pathophysiology of schizophrenia which found variable changes in glutamate receptors and their modulators in schizophrenia [26], [27], [28], [29]. This is also supported by a previous study which reported that the application of antioxidants in clinical trials prevents or reduces disease progression [30].

\section{Conclusion}

The results of this study showed that administration of Vitamin C significantly increases BDNF levels and improves the negative symptoms in schizophrenic patients. More specifically, there was a significant increase in BDNF levels in treatments group compared the control at the $4^{\text {th }}$ and $8^{\text {th }}$ weeks with $p=0.005\left(4^{\text {th }}\right.$ week $)$ and $\leq 0.0001(<0.05)\left(8^{\text {th }}\right.$ week $)$. The improvement in PANSS scores for negative symptoms in the treatment groups compared to the controls at the $2^{\text {nd }}, 4^{\text {th }}$, and $8^{\text {th }}$ weeks resulted in $p=0.042\left(2^{\text {nd }}\right.$ week $)$ and $<0.0001\left(4^{\text {th }}\right.$ and $8^{\text {th }}$ weeks $)$. Furthermore, there was an increase in serum Vitamin $C$ levels in the treatment groups with an initial average value $=4.762$ and after 8 weeks $=148.155$. Strong correlation between increased BDNF levels and improvement in negative symptoms on the PANSS score was found with $p=0.001$ ( $^{\text {th }}$ week) and $\leq 0.0001$ ( $8^{\text {th }}$ week $)$. The administration of Vitamin $C$ significantly increases BDNF levels and improves the PANSS score for negative symptoms in the treatments compared to the control groups.

Overall, the findings found that statistically Vitamin $C$ has a potential effect on changes in BDNF levels and improvement of negative symptoms in schizophrenic patients at a dose of $1000 \mathrm{mg} / \mathrm{day}$ for the $8^{\text {th }}$ weeks of administration. The findings revealed that there is increasing evidence that oxidative stress contributes to the pathophysiology of schizophrenia as indicated by an increase in lipid peroxidation products in plasma and cerebrospinal fluid and an increase in enzymatic and non-enzymatic oxidants in schizophrenia. Due to the large lipid contents and the high oxidative metabolism in the myelin sheath, the brain is a target for free radicals which cause damage. Therefore, oral antioxidant supplementation is given as a secondary therapy to prevent oxidative as well as nerve tissue damage and improve clinical symptoms.

The limitation of this study lies in empirical testing to limit the effect of Vitamin $\mathrm{C}$ on the amelioration of negative symptoms in schizophrenic patients and BDNF levels, and did not examine side effects and mechanisms. Hence, further studies are needed to test side effects and mechanisms of glutamatergic mechanism affecting symptoms of schizophrenia.

\section{References}

1. Kaplan HI, Sadock BJ. Schizophrenia. In: Synopsis of Psychiatry: Behavioral Sciences Clinical Psychiatry. Lippincott Williams and Wilkins Co.; 2015.

2. Amir N, Kusumawardhani A, Husain A, Adikusumo A, Damping C. Buku ajar Psikiatri. Jakarta: Fakultas Kedokteran Universitas Indonesia; 2010

3. Millan MJ, Fone K, Steckler T, Horan WP. Negative symptoms of schizophrenia: Clinical characteristics, pathophysiological substrates, experimental models and prospects for improved treatment. Eur Neuropsychopharmacol. 2014;24(5):645-92. https://doi.org/10.1016/j.euroneuro.2014.03.008

PMid:24820238

4. Correll CU, Schooler NR. Negative symptoms in schizophrenia: A review and clinical guide for recognition, assessment, and treatment. Neuropsychiatr Dis Treat. 2020;16:519-34. https:// doi.org/10.2417/NDT.S225643

PMid:32110026

5. Noto C, Ota VK, Gadelha A, Noto MN, Barbosa DS, Bonifácio KL, et al. Oxidative stress in drug naïve first episode psychosis and antioxidant effects of risperidone. J Psychiatr Res. 2015;68:210-6. https://doi.org/10.1016/j.jpsychires.2015.07.003 PMid:26228421

6. Numakawa T, Suzuki S, Kumamaru E, Adachi N, Richards M, Kunugi $\mathrm{H}$. BDNF function and intracellular signaling in neurons. Histol Histopathol. 2010;25(2):237-58. https://doi.org/10.14670/ hh-25.237

PMid:20017110

7. Nazari H, Heydarpoor S, Mohamadi Mofrad A, Nazari Y Nazari A. Effect of Vitamin $C$ on serum concentration of brainderived neurotrophic factor among healthy inactive young men. Neurosci J Shefaye Khatam. 2016;4(2):27-32.

8. Figueroa-Méndez R, Rivas-Arancibia S. Vitamin C in health and disease: Its role in the metabolism of cells and redox state in the brain. Front Physiol. 2015;6:397-408. https://doi.org/10.3389/ fphys.2015.00397

PMid:26779027

9. Hoenders HR, Bartels-Velthuis AA, Vollbehr NK, Bruggeman $\mathrm{R}$, Knegtering $\mathrm{H}$, de Jong JT. Natural medicines for psychotic disorders: A systematic review. J Nerv Ment Dis. 2018;206(2):81-101. https://doi.org/10.1097/ NMD.0000000000000782

PMid:29373456

10. Dakhale GN, Khanzode SD, Khanzode SS, Saoji A. Supplementation of Vitamin C with atypical antipsychotics reduces oxidative stress and improves the outcome of schizophrenia. Psychopharmacology. 2005;182(4):494-8. https://doi.org/10.1007/s00213-005-0117-1 PMid:16133138

11. Oberlies, T. Vitamins in schizophrenia: $A$ literature review. Indo Iran J. 2012;37(4):333-49. https://doi. org/10.1163/000000094790084162

12. Khodaie M, Alibeigi N, Mirzaei VG. The effect of Ascorbic Acid as supplementary treatment with risperidone in controlling the 
symptoms of schizophrenia: A double-blind, placebo-controlled clinical trial. J Basic Clin Pathophysiol. 2019;7(1):7-14. https:// doi.org/10.22070/jbcp.2019.3616.1104

13. Yusuf M. Perbedaan Total Skor PANSS pada Laki-laki Skizofrenia yang Mendapat Risperidon dengan Penambahan Vitamin C dan yang Hanya Mendapat Risperidon di Rumah Sakit Jiwa Prof. M. Ildrem Medan; 2019.

14. American Psychiatric Association. Diagnostic and Statistical Manual of Mental Disorders. $5^{\text {th }}$ ed. Washington, DC: American Psychiatric Association; 2013.

15. Vahia IV, Palmer BW, Depp C, Fellows I, Golshan S, Kraemer HC, Jeste DV. Is late-onset schizophrenia a subtype of schizophrenia? Acta Psychiatr Scand. 2010;122(5):414-26. https://doi.org/10.1111/j.1600-0447.2010.01552 PMid:20199491

16. Magalhães PV, Dean O, Andreazza AC, Berk M, Kapczinski F. Antioxidant treatments for schizophrenia. Cochrane Database Syst Rev. 2016;2016(2):1-93. https://doi.org/10.1002/14651858. CD008919.pub2 PMid:26848926

17. Moretti M, Fraga DB, Rodrigues AL. Ascorbic acid to manage psychiatric disorders. CNS Drugs. 2017;31(7):571-83. https:// doi.org/10.1007/s40263-017-0446-8 PMid:28600627

18. Zheng $F$, Zhou $X$, Moon $C$, Wang $H$. Regulation of brainderived neurotrophic factor expression in neurons. Int $\mathrm{J}$ Physiol Pathophysiol Pharmacol. 2012;4(4):188-200. https://www.ncbi. nIm.nih.gov/pmc/articles/PMC3544221

PMid:23320132

19. Qian L, Zhao J, Shi Y, Zhao X, Feng G, Xu F, et al. Brain-derived neurotrophic factor and risk of schizophrenia: An association study and meta-analysis. Biochem Biophys Res Commun. 2007;353(3):738-43. https://doi.org/10.1016/j.bbrc.2006.12.121 PMid: 17196936

20. Grillo RW, Ottoni GL, Leke R, Souza DO, Portela LV, Lara DR. Reduced serum BDNF levels in schizophrenic patients on clozapine or typical antipsychotics. J Psychiatr Res. 2007;41(1-2):31-5. https://doi.org/10.1016/j. jpsychires.2006.01.005

PMid: 16546213

21. Toyooka K, Asama K, Watanabe Y, Muratake T, Takahashi M, Someya $\mathrm{T}$, et al. Decreased levels of brain-derived neurotrophic factor in serum of chronic schizophrenic patients. Psychiatry Res. 2002;110(3):249-57. https://doi.org/10.1016/ S0165-1781(02)00127-0

PMid: 12127475
22. Xiu MH, Hui L, Dang YF, De Hou T, Zhang CX, Zheng YL, et al. Decreased serum BDNF levels in chronic institutionalized schizophrenia on long-term treatment with typical and atypical antipsychotics. Prog Neuropsychopharmacol Biol Psychiatry. 2009;33(8):1508-12. https://doi.org/10.1016/j. pnpbp.2009.08.011

PMid:19720106

23. Ikeda $\mathrm{Y}$, Yahata N, Ito I, Nagano M, Toyota T, Yoshikawa $T$, et al. Low serum levels of brain-derived neurotrophic factor and epidermal growth factor in patients with chronic schizophrenia. Schizophr Res. 2008;101(1-3):58-66. https://doi.org/10.1016/j. schres.2008.01.017

PMid:18289832

24. Zhang XY, Xiu MH, De Yang F, Wu GY, Lu L, Kosten TA, et al. Nicotine dependence and serum BDNF levels in male patients with schizophrenia. Psychopharmacology. 2010;212(3):301-7. https://doi.org/10.1007/s00213-010-1956-y

PMid:20661552

25. Nasirin C, Lionardo A. Decentralization, public services and neglected children in Mataram City, West Nusa Tenggara. Rese Horiz. 2021;1(2):55-61. https://doi.org/10.54518/ rh.1.2.2021.55-61

26. Tsai G, Coyle JT. Glutamatergic mechanisms in schizophrenia. Ann Rev Pharmacol Toxicol. 2002;42(1):165-79. https://doi. org/10.1146/annurev. pharmtox.42.082701.160735

PMid:11807169

27. Tamminga CA. Schizophrenia and glutamatergic transmission. Crit Rev Neurobiol. 1998;12(1-2):21-36. https://doi.org/10.1615/ critrevneurobiol.v12.11-2.20

PMid:9444480

28. Menniti FS, Lindsley CW, Conn PJ, Pandit J, Zagouras P, Volkmann RA. Allosteric modulators for the treatment of schizophrenia: targeting glutamatergic networks. Curr Top Med Chem. 2013;13(1):26-54. https://doi. org/10.2174/1568026611313010005

PMid:23409764

29. Gaspar PA, Bustamante ML, Silva H, Aboitiz F. Molecular mechanisms underlying glutamatergic dysfunction in schizophrenia: Therapeutic implications. J Neurochem. 2009;111(4):891-900. https://doi. org/10.1111/j.1471-4159.2009.06325.x PMid: 19686383

30. D'souza B, D'souza V. Oxidative injury and antioxidant Vitamins $\mathrm{E}$ and $\mathrm{C}$ in schizophrenia. Indian $\mathrm{J}$ Clin Biochem. 2003;18(1):87-90. https://doi.org/10.1007/BF02867671 PMid:23105377 